\title{
Perubahan Bentuk Planlet Pisang Raja Sereh Hasil Mutasi dengan Ethyl Methane Sulphonate (EMS) Secara In Vitro
}

\author{
Yulmira Yanti ${ }^{1 *}$, Trimurti Habazar1), Mardinus ${ }^{1)}$, dan Mansyurdin²) \\ 1)Jurusan Hama dan Penyakit Tumbuhan Fakultas Pertanian Universitas Andalas Padang \\ 2Jurusan Biologi Fakultas Matematika dan Ilmu Pengetahuan Alam Universitas Andalas, Padang
}

Diterima 12-02-2008

Disetujui 09-02-2009

\begin{abstract}
The shoot of "rajasereh" banana was treated by $0,2 \%$ and $0,5 \%$ of ethyl methane sulfonate (EMS), for 2 and 4 hours thourgh in vitro. The results showed that treatment of EMS mutagen would be changed morphologycal characters either in planlet. In planlet stage was obtained four morphololgycal variations. One of the variant have characterized the colour yellowish; the leaves and stem are yellowish: the leaves were small and spiral. The value of coefficient of variant for morfphologycal characters of planlet "raja sereh" banana increased compare to the control. The extreme value of coefficient of variant in planlet stage was found the times shoots is $84,31 \%$, while control that is $\mathbf{8 , 2 4 \%}$. EMS mutagen could caused several planlets shorter, total of leaves could of shoot are mostly
\end{abstract}

Keywords: EMS (Ethyl Methane Sulfonate), Mutagen, In Vitro, Morphology “raja sereh" Banana

\section{PENDAHULUAN}

Pisang (Musa sp.) merupakan salah satu jenis buah tropika yang mempunyai potensi cukup tinggi untuk dikelola secara intensif dengan berorientasi agribisnis, karena telah menjadi usaha dagang ekspor dan impor di pasar internasional (Rukmana 1999). Namun demikian produksi pisang cenderung turun dari tahun ke tahun, penurunan produksi tersebut terutama disebabkan oleh serangan hama dan penyakit. Salah satu penyebab turunnya produksi pisang adalah akibat penyakit layu darah (blood disease bacterium), yang disebabkan oleh phytotype IV Ralstonia solanacearum (Fegan \& Prior 2005).

Blood disease bacterium (BDB) menempati urutan pertama dalam daftar penyakit pisang di Indonesia sehingga sangat berbahaya dan mengancam perkebunan pisang (Valmayor 1989). Kerusakan yang ditimbulkannya bervariasi setiap daerah yaitu mencapai $70-80 \%$ di Sulawesi Selatan (Roesmiyanto \& Hutagalung 1989). Sahlan dan Nurhadi (1994) melaporkan bahwa di Provinsi Sumatera Barat, Jawa Barat dan Lampung Penyakit BDB banyak ditemukan pada tanaman varietas ambon, batu (kepok) dan beberapa pisang olahan lainnya.

\footnotetext{
*Telp: 075172701

Email: yy_anthie@yahoo.com
}

Salah satu alternatif untuk pengendalian penyakit BDB pada tanaman pisang raja sereh mungkin dapat dilakukan dengan induksi mutasi. Pemuliaan mutasi secara fisika pada pisang dapat dilakukan dengan menggunakan irradiasi sinar gamma, sinar UV dan sinar mengion (Gardiner 1984; Roux 2004). Menurut Micke (1996) induksi mutasi dengan perlakuan mutagen kimia tergolong praktis dalam pelaksanaannya dan umum dipakai. EPP (1987), Omar et al, (1989), Bhagwat \& Duncan (1998), menyatakan bahwa beberapa macam mutagen kimia yang biasa digunakan untuk melihat induksi mutasi yaitu sodium azide, diethyl sulfat dan ethil methane sulfonate (EMS). Dari beberapa mutagen kimia yang telah dicobakan tersebut EMS memperlihatkan pengaruh dan hasil lebih baik.

Tanaman pisang hasil induksi mutasi dengan mutagen kimia secara in vitro menunjukkan karagaman yang besar (Hwang 1990; Bhagwat \& Duncan 1998). Penggunaan mutagen kimia pada kultur in vitro merupakan teknik yang lebih baik untuk mendapatkan mutan dari pada mutagen fisik (Herawati 1999; Roux 2004).

Mutasi pada tanaman juga dapat diamati dengan adanya perubahan bentuk daun. Secara in vitro perubahan ini dapat dilihat pada planlet yang meliputi warna daun, persentase planlet yang tumbuh, tinggi planlet (Jamaluddin 1995) bentuk daun (Hawa 1996), dan perkembangan tunas dimana tunas sangat sensitif 
terhadap mutagen kmia (Satyanarana et al, 1980; EPP 1987)

Keberhasilan induksi mutasi pada tiap-tiap jenis tanaman tergantung pada jenis mutagen, kosentrasi mutagen, lama perlakuan dan organ tanaman yang diperlakukan. EMS pada umumnya diaplikasikan pada kosentrasi $0,2 \%$ selama 6 jam terhadap biji kacang kapri (Gupta et al, 1996), 0,2\% dan 0,4\% selama 6 jam pada tebu (Sacharum sp.) (Khairwal et al, 1984). Induksi mutasi secara in vitro dengan EMS juga telah dilakukan pada beberapa jenis pisang seperti di antaranya pisang rastali dan pisang mas di Malaysia. Pemberian EMS 0,5\% selama 2 jam pada tunas pisang maka dihasilkan mutan-mutan yang mempunyai karakter dengan kapasitas pertumbuhan yang tinggi serta resisten terhadap penyakit layu Fusarium (Jamaluddin 1995).

Secara umum belum ditemukan pengendalian yang ampuh untuk mengendalikan penyakit tersebut, maka perlu dilakukan induksi mutasi bonggol pisang Raja Sereh dengan pemberian mutagen kimia EMS secara in vitro dengan kosentrasi $0,2 \%$ dan $0,5 \%$ selama 2-4 jam. Tujuan penelitian ini adalah untuk memperoleh perubahan bentuk planlet pisang raja sereh akibat perlakuan mutagen kimia EMS.

\section{BAHAN DAN METODE}

Penelitian menggunakan metoda deskriptif. Induksi mutasi dengan EMS secara in vitro pada bonggol pisang Raja Sereh yang telah bertunas) yang diambil dari rumpun tanaman yang sehat. Perlakuan terdiri dari a) kontrol, b) EMS diberikan dengan kosentrasi 0,2 dan $0,5 \%$ masing-masing selama 2 dan 4 jam. Penelitian ini dilakukan di laboratorium Fisiologi Tumbuhan dan Kultur Jaringan Jurusan Biologi, Fakultas Matematika dan Ilmu Pengetahuan Alam, Universitas Andalas Padang dari bulan Februari sampai Desember 2006.

Pisang raja sereh yang dimutasi secara in vitro adalah kultivar lokal asal Nagari Tabek Panjang Kecamatan Baso Kabupaten Agam. Bahan tanam yang digunakan sebagai eksplan adalah tunas yang berasal dari satu rumpun tanaman sehat dengan ukuran 20-40 $\mathrm{cm}$. Di laboratorium, tunas-tunas pisang tersebut disterilisasi dengan merendam ke dalam larutan kloroks 10\% selama 10 menit, kloroks $5 \%$ selama 5 menit, kloroks $1 \%$ selama 1 menit dan akhirnya dibilas
Tabel 1. Perubahan morfologi planlet pisang Raja Sereh hasil perlakuan dengan EMS

\begin{tabular}{|c|c|}
\hline Perlakuan & $\begin{array}{l}\text { Karakter daun sebelum diaklimatisasi } \\
\text { (195 hari setelah tanam) }\end{array}$ \\
\hline $\begin{array}{l}\text { A1 } \\
\text { Kontrol }\end{array}$ & Warna hijau; penampilan normal \\
\hline $\begin{array}{l}\text { A2 } \\
(0,2 \% 2 \mathrm{jam})\end{array}$ & $\begin{array}{l}\text { Warna kuning pucat; penampilan } \\
\text { keriting;daun batang kuning pucat;daun kecil } \\
\text { tidak beraturan dan seperti spiral }\end{array}$ \\
\hline $\begin{array}{l}\text { A3 } \\
(0,2 \% 4 \text { jam })\end{array}$ & $\begin{array}{l}\text { Warna kuning pucat;penampilan keriting;daun } \\
\text { batang kuning pucat; daun kecil-kecil tidak } \\
\text { beraturan }\end{array}$ \\
\hline $\begin{array}{l}\text { A4 } \\
(0,5 \% 2 \mathrm{jam})\end{array}$ & Warna kuning pucat; penampilan keriting \\
\hline $\begin{array}{l}\text { A5 } \\
(0,5 \% 4 \mathrm{jam})\end{array}$ & $\begin{array}{l}\text { Warna kuning pucat; penampilan keriting; } \\
\text { daun batang kuning pucat }\end{array}$ \\
\hline
\end{tabular}

Keterangan: $\mathrm{A} 1=$ kontrol; $\mathrm{A} 2$ = EMS 0,2\% selama 2 jam; $\mathrm{A} 3=$ EMS $0,2 \%$ selama 4 jam; $A 4=$ EMS $0,5 \%$ selama 2 jam; $\mathrm{A} 5=$ EMS $0,5 \%$ selama 4 jam.

dengan aquades steril sebanyak 3 kali. Tunas yang telah disterilisasi dikupas dengan menggunakan skalpel dalam laminar air flow cabinet (LAFC) sampai berukuran $3 \mathrm{~cm}^{3}$ untuk ditanam. Sebelum ditanam, tunas dibelah membujur menjadi empat bagian. Potongan tunas tersebut kemudian ditanam pada botol kultur (diameter $5 \mathrm{~cm}$ ) yang telah berisi $\pm 20 \mathrm{~mL}$ dalam medium Murashige Skoog (MS) yang telah ditambahkan 2 ppm Benzil Amino Purin (BAP) (Wisnubroto et al, 1994). Selanjutnya kultur diinkubasi pada ruang yang tidak ada cahaya matahari. Tunas yang muncul dari kultur pertama diperbanyak pada subkultur berikutnya.

Medium yang digunakan untuk induksi ketahanan bibit pisang adalah larutan mutagen EMS. Induksi mutasi dilakukan pada tahap tunas yang berumur kirakira 2-3 minggu setelah subkultur dengan munculnya tunas baru. Tunas baru tersebut dipotong dan dikupas batang semunya dan ditinggalkan bagian meristemnya. Selanjutnya tunas tersebut dimasukan ke dalam gelas piala volume $(250 \mathrm{~mL})$ yang telah berisi larutan mutagen EMS. Tunas yang telah diinduksi mutasi dan tanpa induksi (kontrol) di cuci dengan aquadest steril sebanyak tiga kali kemudian dipindahkan ke medium MS yang ditambah dengan 2 ppm IAA, 4 ppm BAP dan $10 \mathrm{~mL}$ air kelapa, kemudian diinkubasi selama 10 
Tabel 2. Nilai rata-rata, varian dan koefisien keragaman beberapa karakter morfologi dari tanaman Pisang Raja Sereh hasil perlakuan EMS dengan berbagai kosentrasi.

\begin{tabular}{|c|c|c|c|c|c|c|}
\hline \multirow[t]{2}{*}{ Perlakuan } & \multicolumn{3}{|c|}{ Jumlah tunas awal } & \multicolumn{3}{|c|}{ Waktu muncul tunas awal } \\
\hline & $x$ & $S^{2}$ & CV (\%) & $X$ (hst) & $S^{2}$ & CV $(100 \%)$ \\
\hline $\begin{array}{l}\text { A1 } \\
\text { (kontrol) }\end{array}$ & 1,30 & 0,05 & 12,40 & 7,50 & 0,45 & 8,24 \\
\hline $\begin{array}{l}\text { A2 } \\
(0,2 \% 2 \text { jam })\end{array}$ & 2,41 & 0,99 & 41,22 & 40,25 & 8,54 & 84,31 \\
\hline $\begin{array}{l}\text { A3 } \\
(0,2 \% 4 \text { jam })\end{array}$ & 2,08 & 0,62 & 38,02 & 32,50 & 6,21 & 59,65 \\
\hline $\begin{array}{l}\text { A4 } \\
(0,5 \% 2 \text { jam })\end{array}$ & 1,91 & 0,38 & 35,48 & 36,58 & 4,85 & 48,14 \\
\hline $\begin{array}{l}\text { A5 } \\
(0,5 \% 4 \text { jam })\end{array}$ & 1,75 & 0,28 & 27,60 & 25,92 & 3,52 & 33,98 \\
\hline
\end{tabular}

Keterangan : $\mathrm{X}=$ Rata- rata hitung, $\mathrm{S} 2=$ Varian, $\mathrm{CV}=$ koefisien keragaman

Tabel 3. Nilai rata-rata, Varian dan koefisien keragaman waktu muncul daun pertama.

\begin{tabular}{lcc}
\hline & \multicolumn{2}{c}{ Waktu muncul daun awal (hst) } \\
\cline { 2 - 3 } Perlakuan & X (hst) & CV(100\%) \\
\hline A1(kontrol) & 152,91 & 20,58 \\
A2 (0,2\% 2 jam) & 32,40 & 27,17 \\
A3 (0,2\% 4 jam) & 64,75 & 32,21 \\
A4(0,5\% 2 jam) & 78,66 & 29,29 \\
A5 (0,5\% 4 jam) & 137,66 & 26,16 \\
\hline
\end{tabular}

Keterangan : $\mathrm{X}=$ Rata-rata hitung, $\mathrm{CV}=$ koefisien keragaman

hari dan selanjutnya diinkubasi diruang yang tidak ada cahaya matahari langsung.

Pengamatan dilakukan terhadap waktu muncul tunas, jumlah tunas yang muncul, morfologi planlet meliputi (warna daun, penampilan daun).

Analisis data dari beberapa karakter hasil perlakuan EMS dinyatakan dengan rata-rata hitung $(X)=$ " $\mathrm{x} i / \mathrm{n}$, varian $\left(\mathrm{S}^{2}\right)=\mathrm{f}(\mathrm{x}-\mathrm{X} \text { rata-rata })^{2} / \mathrm{n}-1$ dan simpangan baku $(S)=$ "S .

\section{HASIL DAN PEMBAHASAN}

Berdasarkan deskripsi morfologi semua individu pada planlet untuk setiap perlakuan diperoleh variasi seperti pada Tabel 1 perlakuan dengan mutagen EMS pada tunas pisang raja sereh secara in vitro menimbulkan perubahan morfologi.

Planlet pisang raja sereh hasil perlakuan dengan mutagen EMS Tabel 1 menunjukkan adanya gejala perobahan warna dari daun menjadi kuning pucat dan penampilan daun menjadi keriting. EMS juga menyebabkan perobahan warna pada batang menjadi kuning pucat serta bentuk daun kecil tidak beraturan dan ada juga yang menyerupai bentuk spiral. Gejala tersebut merupakan efek umum akibat perlakuan mutagen. Raisinghani dan Mahna (1996) melaporkan bahwa induksi mutasi pada tanaman Trigonella corniculata dengan diethylsulfat (DES) dan dimethylsulfat (DMS) pada kosentrasi 0,5\% diperoleh dua karakter daun yaitu Virina xanthascens (hijau muda) dan Xanthina (bercak kuning pada daun. Selanjutnya Rahmi (2003), melaporkan bahwa induksi mutasi pada pisang Ambon dengan kosentrasi EMS 0,3-0,7\% waktu 2-7 jam didapatkan karkater daun hijau pucat berbintikbintik putih menyebar dan kuning kecoklatan. Hal yang serupa tentang perubahan warna pada daun juga sering disebabkan dengan penggunaan mutagen fisik seperti yang dilaporkan oleh Novak et al, (1990) dan MAK (1995) pada pisang Barangan yang menggunakan radiasi gamma 38 Gy terjadi perubahan dari warna daun termasuk juga penghapusan warna, hijau yang lebih gelap, dan berbagai bentuk warna daun. Siti Hawa (1996) juga melaporkan bahwa pisang Nedran varietas yang diiradiasi dengan sinar gama maka terjadi defisiensi klorofil dan bercak pada daun serta tanaman yang albino.

Pada Tabel 2 juga memperlihatkan bahwa varian dan koefisien keragaman pada pisang raja sereh hasil perlakuan mutagen EMS meningkat dibandingkan dengan kontrol. Karakter morfologi yang paling tinggi nilai variannya pada tahap planlet adalah karakter 
morfologi jumlah tunas yaitu 0,99 dan koefisien keragamannya $41,22 \%$, sedangkan pada kontrol varian dan koefisien keragamannya yaitu 0,05 dan $12,4 \%$. Varian waktu munculnya tunas pada perlakuan $0,2 \%$ selama 2 jam yaitu 8,54 dengan koefisien keragamannya $84,31 \%$, sedangkan varian dan koefisien keragaman kontrol adalah 0,45 dan $8,24 \%$. Meningkatnya nilai varian dan koefisien keragaman menunjukkan besarnya variasi pisang raja sereh hasil perlakuan mutagen EMS secara in vitro pada tahap planlet. Jamaluddin (1995) melaporkan bahwa perlakuan 0,5\% EMS selama 2 jam pada tunas pisang Mas dan Rastali dapat meningkatkan variasi morfologi sebesar $30 \%$. Selanjutnya Rahmi (2003), melaporkan bahwa induksi dengan mutagen EMS 0,3-0,7\% selama 2-6 jam pada tunas pisang Ambon menghasilkan jumlah tunas yang bervariasi.

Waktu munculnya daun awal atau daun pertama (Tabel 3) dapat dilihat nilai rata-rata tanaman hasil induksi mutasi waktu munculnya daun pertama lebih cepat dibandingkan dengan tanaman kontrol. Penggunaan mutagen EMS meningkatkan koefisien keragaman pada pengamatan waktu muncul daun pertama. Pada tanaman perlakuan induksi mutasi dengan koefisien keragaman $27,17 \%$ dan terendah pada perlakuan EMS 0,5\% selama 5 jam dengan koefisien keragaman sebesar $26,16 \%$ dan yang paling rendah pada kontrol dengan koefisien keragaman sebesar $20,58 \%$. Meningkatnya nilai koefisien keragaman waktu munculnya daun pertama pada pisang Raja Sereh hasil induksi mutasi menunjukkan peningkatan keragaman genetik untuk sifat ketahanan terhadap penyakit yang diduga akibat telah terjadinya induksi mutasi dengan EMS pada tunas pisang raja sereh. Jamaluddin (1995) melaporkan bahwa perlakuan 0,5\% EMS selama 2 jam pada tunas pisang mas dan rastali dapat meningkatkan variasi morfologi sebesar 30\%. Dihasilkan beberapa karakter planlet pisang Raja Sereh hasil perlakuan dengan mutagen EMS, jumlah tunas lebih banyak, waktu muncul tunas dan daun awal hal ini menunjukkan perubahan fenotip yang besar yang akan memberikan harapan perbaikan varietas serta adanya keragaman yang besar maka peluang seleksi juga akan semakin besar.

\section{KESIMPULAN}

Berdasarkan data-data perubahan bentuk morfologi planlet pisang raja sereh hasil mutasi dengan EMS secara in vitro dapat disimpulkan bahwa perlakuan dengan mutagen EMS secara in vitro didapatkan empat variasi morfologi. Karakter morfologi yang paling tinggi adalah waktu muncul tunas yaitu 7,54 dengan koefisien keragaman $84,33 \%$. Perlakuan dengan mutagen EMS secara in vitro juga menimbulkan waktu yang bervariasi pada munculnya daun pertama pada setiap planlet.

\section{UCAPAN TERIMAKASIH}

Ucapan terimakasih kepada Prof. Dr. Mardinus Prof. Dr. Trimurti Habazar, Prof. Dr. Mansyurdin yang telah banyak memberi waktu dan saran selama penelitian ini. Serta spesial to Ari yang telah membantu mencarikan literatur dan bahan selama melakukan kegiatan ini.

\section{DAFTAR PUSTAKA}

Bhagwat, B \& Duncan, E. J. 1998. Mutation breeding of banana c.v. Highgate, (Musa spp., AAA grup) for tolerance to Fusarium oxysporum f. sp. cubence using chemical mutagen. Musarama 12: 5-15.

EPP, M. D. 1987. Somaclonal Variation in Bananas: a case study with Fusarium wilt, Banana and Plantain Breeding Breeding Strategies (Persley, G.J., De Langhe, E.A., Eds). ACIAR. Canberra 21: 140-150.

Fegan \& Prior. 2005. Bacterial Wilt Disease and the "Ralstonia solanacearum species complex" (Eds by C. Allen., P. Prior., A.C. Hayward) St. Paul. USA: APS Press.

Gardiner, E. J. \& Peteer, S. 1984. Principles of Genetic. Seventh Edition, New York. Chichester: Brisbhani Toronto Singapore.

Gupta, P.K., Singh, S. P. \& Bahl, J. R. 1996. A new mungbean variety through induced mutation. Mutation Breeding Newsletter 42: 6-7.

Hwang, S.C. 1990. Somaclonal resistence of Cavendish banana to Fusarium wilt. Proc. Of Regional Tehnical Meeting on Disease Affecting banana and Plantain in Asia and Pasific, Brisbane. Australia, 15-18 April 1990.

Herawati Tin. 1999. Pemuliaan Tanaman Lanjutan. Program Pengembangan Kemampuan Peneliti Tingkat S1 Non Pemuliaan dalam IImu dan Teknologi Pemuliaan. Bandung

Jamaluddin, S.A. 1995. Mutation breeding of banana in Malaysia, Musarama 7: 5-20.

Khairwal, I.S, S. Singh \& Paroda. 1984. Indiced mutation in surgance. Surgance 3: 14-16

Micke, A. 1996. 70 years included mutations to be reconsidered? Mutation Breeding Newsletter 42: 22-24.

Novak, F.J. 1990. Mutation induction by gamma irradition of irradition of in vitro cultured shoot-tips of banana and plantain (Musa cvs). Trop. Agr. Trinidad 67: 21-28

Mak, C. 1995. Early screening techniques for Fusarium wilt resistance in banana micropagated plants.

Omar, M. S., F. J. Novak \& Brunner. 1989. In vitro action of Ethyl Methane sulfonate on banana shoot tips. Scientia Hortic 40: 283-295 
Ortiz \& D. R. Vulysteke. 1995. Expression of the dihydroflavonoid reductase gene in anthocyanin-free barley mutant. Hereditas 119: 67-75.

Rukmana, R. 1999. Usaha tani Pisang. Yogyakarta: Penerbit Kanisius.

Rahmi, A. 2003. Induksi mutasi pisang Ambon dengan Senyawa Kimia. Skiripsi Sarjana Biologi FMIPA- Universitas Andalas Padang.

Raisinghani,G. \& S.K. Mahna. 1996. Behaviour of two induced chlorophyll mutants of Trigonella cornicullata L. Mutation Breeding Newletter 42:17-18.

Roesmiyanto \& Hutagalung. 1989. Penyakit Darah (Pseudomonas celebensis) pada tanaman pisang di Senoponto, Sulawesi Selatan. Holtikultura 27: 39-41.

Roux, N.S. 2004."Improved methods to increase diversity in Musa using mutation and tissue culture techniques" (Report of second Research Co-ordination Meeting of culture $\mathrm{FAO} /$
IAEA/BADC Co-ordinated Research Project) Kuala Lumpur. 49-56.

Sahlan \& Nurhadi. 1994. Inventarisasi penyakit pisang di sentra produksi Sumatera Barat, Jawa Barat dan Lampung. Penel. Hort. 6: 36-43.

Satyanaraya, M, Y. Tatacharu \& T.B., Dasarady. 1980. Effect of chemichal mutagen on sporouting and survival of banana corm, Musarama 8: 36-64.

Siti Hawa. 1996. The generation of variants of musa CV Rastali $(A A B)$ through in vitro gamma radiation evaluotion for important agronomic traits. Musarama 12: 50-71.

Valmayor, R.V. 1999. Banana and Plantain in the Pilipines In : Banana Plantain R and D in Asia and the Pacific proceeding of a Regional Consultation on Banana and Plantain $R$ and $D$ Networking Manila and Davno 87-120.

Wisnubroto, Syaifulla \& Satsijati. 1994. Hasil Penelitian holtikultura Pelita V. Jakarta: Puslitbangtan. 